Original research article

\title{
The need for cultural competence education in nursing degree programmes: comparative perspectives
}

\author{
Mirko Prosen ${ }^{1 *}$, Sandra Bošković ${ }^{2}$ \\ ${ }^{1}$ University of Primorska, Faculty of Health Sciences, Department of Nursing, Izola, Slovenia \\ ${ }^{2}$ University of Rijeka, Faculty of Health Studies, Department of Nursing, Rijeka, Croatia
}

\begin{abstract}
Objective: The purpose of this study was to define and compare the experiences, feelings and needs of Slovenian and Croatian nursing students in relation to the concept of transcultural nursing.

Design: A qualitative descriptive research design was used.

Methods: A purposive sample of 15 Slovenian and 15 Croatian nursing students was selected. The data were collected through an openended questionnaire and analysed using the method of content analysis.

Results: Three categories were identified: (1) understanding interculturalism; (2) recognition of the importance of intercultural awareness; (3) integration of cultural content into the curriculum.

Conclusions: The opinions held by Slovenian and Croatian students on the way to integrate cultural content into the curriculum differ; the former favour including this content in existing courses, while the latter argue in favour of a separate course. Designing a study programme in nursing is a demanding task to which both students and faculty are committed.
\end{abstract}

Keywords: Cultural competence; Curriculum; Higher education; Transcultural nursing

\section{Introduction}

As they engage with patients of different cultural backgrounds on a daily basis, nurses and other health care professionals focus their efforts on the reduction and prevention of health inequalities. More often than not, these inequalities stem from cultural barriers, inadequate competences and intercultural skills of the health professionals and their existing prejudices and stereotypes (Cupelli, 2016). The provision of equal, high-quality nursing care, which takes into account the patient's cultural background, is the legal and moral responsibility of each nursing professional (Prosen, 2015; Repo et al., 2017). Over the past two decades, the development of cultural competence among health professionals has been recognised as the most important step toward the prevention of health inequalities - with cultural competence seen as a regular and indispensable part of the curricula of study programmes which lead to careers in nursing (Cupelli, 2016). As noted by several authors (Baumann and Blythe, 2008; Jeffreys, 2014a; Pajnkihar et al., 2019; Prosen, 2018; Prosen et al., 2017), this has increased the need to design study programmes in the field of nursing that will yield highly qualified and culturally competent nurses equipped to function (and seek employment) within diverse cultural environments. The field of nurs- ing must therefore respond in a timely manner to the global challenges posed by the vulnerability of humankind and the inequalities between people created by social conflicts, demographics and climate change. The concepts and perspectives included in nursing curricula should comprise not only cultural aspects, but also general practical knowledge gleaned from the fields of economics, politics, social structure and demography, and should be aimed towards addressing the needs of people, i.e., patients, in a global sense (Holmgren and Kraft, 2018; Hyett et al., 2018). Introducing such topics, however, is not as simple as it might seem. There is a need for new and innovative approaches in education which place an emphasis on internationalisation, thus equipping those entering the labour market with the ability to effectively respond to the diverse needs of individuals of different cultural backgrounds, linguistic groups and worldviews (Campesino, 2008; Hyett et al., 2018). Ignoring cultural diversity and providing nursing care which overlooks the cultural aspect of patient care can result in substandard medical treatment and even endanger patient safety (Jeffreys, 2014b; Sairanen et al., 2013). In the United States (USA) and in some Western European countries, this awareness has resulted in cultural competence education becoming a standard part of the curricula in nursing degree programmes (Cruz et al., 2016; Holmgren and Kraft, 2018; Jeffreys, 2014a; Sairanen et al., 2013; Smit and Tremethick, 2013), while in

\footnotetext{
* Author for correspondence: Mirko Prosen, University of Primorska, Faculty of Health Sciences, Department of Nursing, Polje 42, 6310 Izola, Slovenia; e-mail: mirko.prosen@fvz.upr.si http://doi.org/10.32725/kont.2020.022 
Slovenia and Croatia, efforts continue to introduce this content (Bošković et al., 2017; Ličen and Plazar, 2015; Prosen, 2015; 2018; Prosen et al., 2017; Rinćić et al., 2014).

The purpose of the study was to gain insight into the experiences, attitudes and needs of Slovenian and Croatian nursing students associated with intercultural health care, so as to define, compare, and ultimately use the findings as starting points for the creation of joint educational activities that would contribute to the development of cultural competence in nursing students. To this end, the following research questions were posited: (1) What are the experiences and needs for cultural competence education in nursing degree programmes according to a sample of Slovenian and Croatian nursing students? (2) How do the perceptions of their experiences and needs differ?

\section{Materials and methods}

\section{Design}

For the purposes of this study, a qualitative descriptive research design was used. As an intrinsically descriptive, and to some extent also interpretative form of research, it is a particularly common approach in qualitative research in the field of health care and nursing. This approach has also been identified as significant and suitable for addressing research questions addressing the who, what and where of a given issue in other words, in studies aiming to gain insight into a poorly understood phenomenon. A qualitative descriptive approach is particularly desirable when we aim for a clear description of a phenomenon, or wish to obtain information which might facilitate the development and improvement of our research instruments or interventions (Bradshaw et al., 2017; Kim et al., 2017; Polit and Beck Tatano, 2014; Sandelowski, 2000; Smythe, 2012).

\section{Sample}

The study included part-time third-year students enrolled in the undergraduate study programme of Nursing at the Faculty of Health Sciences of the University Izola, Slovenia, and parttime first-year students enrolled in the postgraduate study programme of Nursing at the Faculty of Health Studies of the University Rijeka, Croatia. When recruiting participants, specific attention was paid to their experience in clinical practice. In Slovenia, the target sample consisted of 15 students, 5 male and 10 female, whose average age was 28.3 years. Their average length of work experience in clinical practice was 9.8 years. During the study, most $(n=10)$ were employed at primary health care facilities. In Croatia, the sample consisted of 15 students, 14 female and 1 male. Their average age was 38.6 years, and their average length of work experience was 18 years. Most $(n=13)$ were employed at secondary and tertiary health care facilities.

\section{Data collection}

The survey was made up of a questionnaire containing seven open-ended questions in its content-related section, and four questions on demographic data. Questions were related to the participants' experience (e.g., characteristics and frequency of their intercultural clinical encounters), attitudes (e.g., associated with the sense of importance of providing holistic health care) and knowledge (e.g., assessment of one's own knowledge and expressed needs for inclusion of cultural content in formal education), whereby attention was paid to the sequence of questions (Holloway and Galvin, 2016). Two identical versions of the questionnaire were created in the Slovenian and Croatian languages. The questionnaire was distributed to students in Slovenia in January 2018, and to students in Croatia in July 2018.

\section{Data analysis}

The data were analysed using the content analysis method, as this method provides the most direct manner of investigating a phenomenon (Bradshaw et al., 2017) and was also deemed the most appropriate for the purpose and aims of our study. The subjects' responses were transcribed into Slovene for Slovenian participants and Croatian for Croatian participants. Each transcript was assigned a code consisting of the first letter of the participant's gender (F (female) or M (male)), the international two-letter country code (Slovenia - SI or Croatia $\mathrm{HR}$ ) and the number of years of employment (an alphabetic sequence of letters was added to repeat responses). Due to the authors' fluency in the two languages, translation of texts into the respective languages was not required in the analysis phase, but was performed afterwards - at the stage of presenting the results. Once the transcription was completed, the data were entered and analysed using the NVivo version 10 software (QRS International, Victoria, Australia). The method of content analysis (Bradshaw et al., 2017; Elo and Kyngas, 2008; Erlingsson and Brysiewicz, 2017; Graneheim and Lundman, 2004 ) began by reading all the answers to create an impression of students' experiences, feelings and knowledge in relation to the provision of transcultural nursing. Since the method of content analysis is a highly reflexive process, the first potential analytical conclusions were already revealed at this stage. The authors therefore entered their comments and took them into account in the final part of the analysis. In the next stage of the analysis, parts of the text were broken down into individual semantic units/segments. These were then dissected into even smaller semantic units whilst maintaining their original significance with regard to the overall context. Smaller semantic units were assigned meaning (coding). Individual codes were then compared on the basis of their differences and similarities and classified into categories and subcategories reflecting the content (Polit and Beck Tatano, 2014). The final results (categories and subcategories) were separately analysed by both authors, and the final concept was determined through a discussion and consensus.

\section{Results}

Three categories were identified in the analysis: (1) perception of interculturalism, (2) perceived importance of cultural knowledge, (3) integration of cultural content into the curriculum.

\section{Perception of interculturalism}

All participants reported having frequent encounters with patients from other cultures. Both groups perceive contact with a patient who adheres to Islam as an encounter with another culture, and this was reported as being the most common type of cultural encounter. A more detailed overview of the responses reveals minor differences between the two groups; for example, Croatian students listed other cultural groups typical of the summer tourist season, while Slovenian students stated having much more frequent encounters with citizens of former Yugoslavia. In addition to followers of Islam, both groups also mentioned members of the Orthodox Church and Jehovah's Witnesses. Two respondents from the Croatian group 
mentioned the Roma. Migrants were only mentioned rarely and mostly in the context of migrant workers. Both Slovenian and Croatian students seem to perceive the definition of 'culture' as mostly related to religion and not to other cultural characteristics. In one case only, a Slovenian student refers to a visually impaired patient as a person of a different culture.

"In my long years of practice, I have frequently come into contact with patients from other cultures. When I was working in this clinic (name mentioned, A/N), I often came into contact with patients from Angola and Libya. Later on, also with patients from Kosovo [...] There has also been contact with patients who are tourists; this is, after all, a tourist country" (F_HR_10).

"Yes, often, because I live in an environment where there are many people from the Balkan countries, who have different faiths and traditions" (M_SI_7).

In some responses, there seems to be an emphasis on perceiving interculturalism on the basis of subordination and unilateral adaptation. Although such cases were few, the responses do reveal that in the context of the application of interculturalism in health care this kind of mindset is not uncommon. There is a belief that respect for a patient's cultural background in the provision of health care is equated with the belief that intercultural action means a complete subordination and adaptation of health care to the patient's culture. This simply does not hold true, as there are cultural habits which may endanger one's life or significantly impair its quality. Although respect for cultural habits is important, in most Western societies there are restrictions imposed on certain traditions.

"... intercultural health care means to conform to the cultural demands of another culture" (F_SI_10).

"We have to adapt to the patient of another culture" (F_ HR_16).

In contrast, the vast majority of Slovenian and Croatian respondents see the provision of transcultural health care primarily as one based on respect for other cultural habits, customs and traditions.

"... it is necessary to take into account the customs of other people and to respect them" (F_SI_19).

"... in my experience (which is rather limited), I have noticed that there are many differences between cultures, and concluded that our professional approach should change in a way that would respect such differences..." (F_HR_3b).

The same student continues:

"... it is also necessary to educate both health care professionals as well as patients (although I feel that it is often patients rather than health care professionals who have more awareness and demand respect for their culture, but they do not know and are not informed about the importance of certain procedures and do not realise that sometimes we cannot take into account their every request - the principle of culture)" (F_HR_3b).

In this respect, it is necessary to seek compromises and to balance the cultural requirements of the patient with the demands of the profession, although this is a demanding process.

"I myself was personally raised differently - as a Muslim, and faith tells us that, if possible, the intimate hygiene of women should be performed by women (nurses, $\mathrm{A} / \mathrm{N}$ ) and that of men by men (health technicians, male nurses, A/N). However, this should not be a demand that would clash with the law or organisation of work, and least of all harm one's own health and the health of others" (M_SI_7a).

"During the night, a woman in labour accompanied by her husband arrived at the maternity ward; they were from Pakistan. Communication was difficult due to the language barrier, labour had already started, but the husband insisted that the birth be led by a female gynaecologist - as their culture and religion do not allow other men to look at and touch another's wife. At that time we did not have any female gynaecologists at our ward and we could not fulfil his request. Contractions were already very intense, but the husband would not allow her to lie on the birthing bed. Feelings of powerlessness, fear for the fetus, anger, they all merged into one. Finally, an agreement was reached that the husband would be present while the gynaecologist performed the episiotomy. [...] During our working hours we encounter many situations, some very unfavourable, where you simply don't know how to react, what to do and how to reach a compromise for mutual benefit" (F_HR_27).

\section{Perceived importance of cultural knowledge}

In both the Slovenian and Croatian groups of respondents, cultural knowledge was recognised as an element of quality health care. Slovenian students expressed the quality of medical treatment through the words "holism", "trust" and "communication".

"These topics are very important for our work, as the patient must come first and needs to be treated in a comprehensive manner. If this is ensured, the patient will be content and we will also establish a strong connection and positive communication, which is very important" (F_SI_17).

Croatian students highlighted the fact that intercultural knowledge enables the provision of an individual approach, i.e., patient-directed health care (also to migrants). In this context they refer to their work with the words "professional", "professional approach" and "expert".

"... with regard to the possibilities, this enables me to approach each patient individually and to try to positively respond to their cultural beliefs" (F_HR_28).

"Knowledge is important as it would help medical staff better understand the patient's needs and requests. I believe that this would also increase patient satisfaction" (F_HR_9).

The need for cultural knowledge was perceived as even more indispensable in the context of providing health care at a patient's home.

"I do not have much experience with patients of other cultures who are being treated in a health care institution, as I do my job mainly at their homes, but I do think that the situation is even more delicate at one's home, as a more careful approach and sound intercultural knowledge are necessary here" (F_HR_3b).

The mentioned need to ensure equal treatment is particularly evident in the Slovenian and Croatian students' recognition of the fact that intercultural knowledge prevents or reduces the possibilities of developing prejudices and stereotypes.

"... to understand patients rather than judge them" (F_SI_8).

"Knowledge is important, as it enables us to treat all patients equally and provide them with the best possible treatment and care" (F_HR_9).

"Personally, I do not harbour prejudices. [...] What counts is that we are all human beings, everything else is a product of good will and mutual tolerance" (F_HR_10).

Despite most of the participating Slovenian and Croatian students recognising the importance of cultural knowledge in the fight against inequality, there are still noticeable prejudices present among our participants - as well as in the clinical practice they report on. Croatian students seem to report more openly about the latter.

"... as far as my colleagues are concerned. Some would sometimes be rude to them (referring to the Roma, A/N.)" (F_HR_3a).

"The only experience I have is rejection of blood and blood components during a surgical treatment - and the related ignorance of medical staff, rebellion, revolt and negative comments" (F_HR_12). 
There is also a discernible misinterpretation of culture, which demonstrates that this is an aspect which should be addressed in more detail in the nursing curriculum.

"According to my work experience, I believe that, with all due respect, we care for other cultures too much, while at the same time failing to respect our own. I have encountered situations where Christian patients told us that their cultural views were not being respected and no one even took any notice as they are our people, but God forbid if we should behave like this to other cultures. There would be an immediate disciplinary hearing and sanctions" (F_HR_28)

Talking openly about interculturalism and the acquisition of related knowledge or even "acting in a culturally sensitive manner" does not seem to be desirable. A Slovenian student acknowledges this:

"In my opinion... We are not really prepared to talk about it. We are afraid. We are full of prejudices" (M_SI_7a).

Both Slovenian and Croatian students recognised cultural knowledge not only as a powerful instrument in the fight against health inequalities, but also as an important tool for the prevention of intercultural conflicts, i.e., "cultural conflicts" - as the phenomenon was referred to by the students.

"[...] knowledge helps us avoid cultural conflicts!" (F_SI_8).

"It is good that we know different cultures, their habits and customs. This way, we can avoid unpleasant situations" (M_SI_14).

\section{Integration of interculturalism into the curriculum}

According to their responses, a vast majority of the Slovenian students $(n=12)$ learned about interculturalism during their undergraduate studies; mostly during the course Sociology of Health and Illness, and partly during the course Community nursing and primary care. Four respondents noted that they also acquired information on interculturalism from their work environment, while two listed non-formal education as their source of information. One student emphasised obtaining information from the media. In comparison, half of the Croatian respondents stated that they received information on interculturalism at university. Others stated that they had not yet heard the terms intercultural nursing, intercultural nursing care or transcultural nursing, and indicated the need for additional information (e.g., in the form of a lecture). With the exception of four Croatian students, all other participating students expressed a clear need to obtain intercultural knowledge. Similarly, all the Slovenian students expressed the need for additional knowledge. However, there are certain differences between the Slovenian and Croatian groups in terms of the form of the desired integration of these topics into the curriculum. Croatian students were much more vocal in this respect.

A total of eight Slovenian students found it most appropriate to distribute cultural topics across existing courses, while five students deemed a dedicated (stand-alone) course focusing on these topics a much more appropriate form of training. Two of them pointed out:

"We need to learn more about the cultures living in our country" (F_SI_1b).

"It would be good to hear more, as I think this will provide us with a breadth of knowledge, which we can then put into practice" (M_SI_7).

In the context of learning about other cultures or ethnicities living in her country of residence, one Croatian student suggested a learning approach which would actively engage members of the co-habiting cultural groups.

"If the stand-alone course of interculturalism is introduced, please do not theorise, but instead invite representatives of the culture being dealt with to lectures" (F_HR_23).
One Slovenian student also proposed a combination of a stand-alone course and an integration of specific topics related to the provision of transcultural health care in specific areas of nursing.

"Both. The theory should first be covered in a stand-alone course, while domain-specific topics should be incorporated into existing ones" (M_SI_15).

A Croatian student was of a similar opinion.

"Intercultural differences, nursing care, etc., can be highlighted within each course; but I think this is a complex topic which deserves to be included into the university programme as a standalone course" (F_HR_27).

Overall, nine Croatian students expressed the desire to place the topics related to interculturalism in nursing into a stand-alone course, which, according to some participants, should not be an elective course.

"I think that topics related to interculturalism in health care should be implemented as an individual course, as this is a very broad subject and needs to be dealt with in detail in order to provide as much information as possible" (F_HR_3b).

"I think it should be a compulsory course. Not at all an elective one. We must be an open-minded society in the way we treat others who might be different from us. This makes us rich" (F_HR_23).

\section{Discussion}

In general, the acquisition and development of cultural competence is becoming a priority in nursing and health care, particularly in light of a changing demographic structure and migrations (Prosen et al., 2017). Today, however, we tend to mostly ascribe the reasons for this to globalisation and the mentioned migration flows and migrants we come into contact with in the clinical environment, but to a much lesser extent to the cultural diversity present within our cultural group. Awareness of cultural diversity can be defined as an active, continuous and conscious process during which an individual is proactively aware of the similarities and differences within and between different cultural groups. This process encourages us to assess the patients' medical condition with due consideration of their culture and an exchange of cultural knowledge and experience with other medical professionals. The goal of both is to improve the medical outcomes of the patient's treatment and to encourage mutual cooperation in a multicultural environment (Jeffreys, 2014c). Ignoring this aspect or perceiving it as just a minor part of nursing care would mean not providing culturally sensitive nursing or nursing care, or even endangering the patient's health and safety. The expectations of not only patients but also employers are therefore directed towards equipping health care professionals with adequate training in providing effective nursing or nursing care to a culturally diverse population of patients. These requirements are also clearly reflected in the design of healthcare-related study programmes aiming to address these needs or problems and encouraging the development of cultural competence in students during their course of studies. Study programmes in the field of nursing must also develop the educational strategies that lead to the achievement of these goals (Smit and Tremethick, 2013). Studies conducted to date show that the changes to the curricula directed towards introducing content related to interculturalism have contributed significantly to the development of cultural competence among students and medical professionals, as well as to an increase in patient satisfaction with the services provided (Wang et al., 2018). 
There are currently many educational strategies for the integration of cultural content into the nursing curriculum: the application of the conceptual theory or model, vertical and horizontal integration of content, integration of these concepts into clinical training, introduction of self-learning modules, integration of research and evidence-based practice, guiding students through independent study, integration of simulation learning, etc. (Sagar, 2014). However, the introduction of a certain strategy should not be chosen randomly and without reason. On the contrary, it must reflect the wishes and needs of students related to the way in which they wish to acquire knowledge and skills. In fact, the primary aim of the present study which involved Slovenian and Croatian students was to recognise the needs for cultural knowledge, and to gain an insight into their perception of this concept and their need to acquire the relevant skills. While the results revealed many similarities between the two groups of students, they also revealed certain differences, particularly in the way the students wish to obtain this knowledge.

It is quite apparent that most Slovenian and Croatian nursing students experience interculturalism on the basis of nationality and religion. In their responses, they mentioned no other culture-specific features in patients. This facet alone reveals a need for further clarification and interpretation of intercultural engagement. This need is further corroborated by their responses associated with the provision of health care: the opinion of some students, and apparently also of other professionals in clinical practice, indicates that intercultural health care is regarded as subordination to the patient's culture, which does not benefit anyone, least of all the patient. The founder of transcultural nursing, Leininger (2002), describes the role of a nursing professional as preservation or maintenance of cultural care, adaptation of cultural care and/ or negotiation and restructuring of cultural care and/or establishing new patterns. It is extremely encouraging that a great majority of students recognise and equate interculturalism with respecting the culture of the patient - as this significantly influences the development of cultural competence and the improvement of the quality of nursing care. The latter was recognised by Slovenian and Croatian students alike, with both groups emphasising holistic or patient-oriented health care. The practice of nursing is inevitably focused on the patient; therefore providing culturally sensitive nursing care is of fundamental importance if we want this concern to be appropriate, effective, of high quality (Cupelli, 2016; Gallagher and Polanin, 2015), and equal for all (Prosen, 2018; Repo et al., 2017). Even though most Slovenian and Croatian students recognized the fact that prejudices and stereotypes (including racism and discrimination) stand in the way of equal treatment, individual responses are indicative of their existence. This is an indicator that this issue should be further addressed in the conceptual structure (topics) of the curriculum. Most responses, however, reveal the presence of cultural humility, i.e., providing care to individuals of other cultures without stereotyping or judging. This is a lifelong process which requires self-reflection, critical thinking and willingness to learn from others, so as to build a partnership with the patient in providing health care (Montenery et al., 2013), and this is in fact exhibited by the vast majority of the respondents. This process promotes respect and demands that one assumes a responsible role in interacting with patients - the ability to assess one's own beliefs and values, the ability of cultural immersion, active listening and flexibility of negotiation. Integrating the concept of cultural humility leads to improved patient satisfaction, interpersonal relationships with health professionals, adherence to medical advice, and contributes to reducing health inequalities (Chang et al., 2012).

Numerous attempts have already been made to formally integrate the topics of intercultural content into the curriculum of nursing education, either in the form of a stand-alone course or as part of the topics dealt with in other courses (Prosen, 2018). In the United States, only a few undergraduate nursing programmes offer this content as an autonomous course, while most place them within other courses - mainly for fear of overburdening the students' course load (Sagar, 2014). Our study shows that Slovenian undergraduate students of nursing wish for intercultural topics to be integrated within already existing courses, while the majority of Croatian students at postgraduate level would rather see this as a standalone course. At least half of them also wish to learn more about interculturalism, as they feel they do not have sufficient information on the topic. Sagar (2014, p. 56) notes that many authors emphasise the benefits of a separate course, especially in the undergraduate nursing study programme, as such an approach ensures that the content is adequately delivered in full rather than being "hit or miss". Recent findings show that effective educational interventions aiming to enhance nursing students' cultural competence must be based on the following features: a stand-alone subject, regular sessions of a sufficient frequency over a semester or academic year, the teaching of both theory and skills, inclusion of a role model or mentor, opportunities for cultural encounters and knowledge transfer (Wang et al., 2018).

The findings of our study indicate the need to activate certain changes in educational approaches and direct a more specific effort towards placing interculturalism-related topics into the nursing curriculum of undergraduate and postgraduate study programmes. On the part of some of the Slovenian respondents, there may have been some fear of having to complete additional course work in an already full curriculum, while some Croatian students (mostly those with over 20 years of employment) seem to need an explanation of the concept of interculturalism. The future development of the curriculum is an opportunity for its internationalisation, as well as an opportunity for mutual cooperation in the creation of a joint curriculum in the field of interculturalism, which would enable, at least in part, a cultural immersion of Slovenian and Croatian nursing students. At the same time, this also raises questions for future investigation, especially in the field of methodology and didactics.

There are some limitations to our study. Its findings cannot be generalised; however, they can be discussed in the context of nursing programmes in higher education. One of the constraints of the survey lies in its structured questions, as they might limit the participants in their responses. In order to remedy this shortcoming, at the end of the questionnaire, an open-ended question offered the respondents an opportunity to describe their experiences or provide opinions they were not able to express by answering the questions. In this kind of qualitative research, which involves no "face to face" interaction and where the researcher must rely on the responses provided, it may happen that despite repeated reading, certain parts of the text are understood differently from the way the participant had intended. In order to avoid this, the two authors collaborated in the analysis as much as possible and, in cases of doubt regarding the meaning, negotiated a decision. Another potential constraint may also be the difference in the cultural contexts in which the research was conducted, whereby the questions in one or the other language may have been written, understood and interpreted differently, or may 
even have been affected by the presence of a researcher during the completion of the questionnaire (Pahor et al., 2015). It should also be taken into account that the survey included participants with work experience in clinical practice in order to gain insight into the needs of employees regarding their needs related to intercultural education. This means that the perception of such needs by full-time students with no work experience would, of course, have been different. The difference in the perception of such needs might have been influenced by certain information the students had heard during their studies, after all, these are students in undergraduate and post-graduate study programmes.

\section{Conclusions}

The primary goal of integrating intercultural content into the nursing curriculum is to foster cultural awareness in prospective nursing professionals in order for them to be able to provide high-quality nursing care regardless of the cultural environment. From the perspective of the teacher, however, this is a demanding process of constant self-appraisal, opportunity seeking, supplementing and amending educational methods to achieve this goal. Our research has shown Slovenian and Croatian students possess cultural awareness, but at the same time, it has shown a number of challenges that need to be addressed in the future.

\section{Conflict of interests}

The authors declare no potential conflict of interests with respect to the research, authorship, and/or publication of this article.

\section{Ethical considerations}

The Institutional Review Board of both participating institutions approved the survey. In both groups, the questionnaire was distributed at lectures, with students having been informed in advance of the purpose and aim of the research, method of investigation, the voluntary nature of their participation and assurance of anonymity. The authors were not present during the participants' completion of the questionnaires.

\section{Potřeba edukace v oblasti kulturní kompetence v oboru ošetřovatelství: komparativní perspektivy}

\section{Souhrn}

Cíl: Účelem této studie bylo definovat a porovnat zkušenosti, pocity a potřeby slovinských a chorvatských studentů ošetřovatelství v souvislosti s konceptem transkulturního ošetřovatelství.

Design: Byla použita metoda popisné kvalitativní studie.

Metodika: Byl účelně vybrán vzorek 15 slovinských a 15 chorvatských studentů ošetřovatelství. Sběr dat byl proveden prostřednictvím otevřeného dotazníku a pro analýzu byla použita metoda obsahové analýzy.

Výsledky: Byly identifikovány tři kategorie: (1) porozumění interkulturalismu; (2) uznání důležitosti mezikulturního vědomí; (3) integrace kulturního obsahu do osnov.

Závěr: Názory slovinských a chorvatských studentů na zpo̊sob, jak integrovat kulturní obsah do učebních osnov, se liší; první z nich dává přednost zahrnutí tohoto obsahu do stávajících kurzů, zatímco druhý se vyslovuje pro samostatný kurz. Vypracování studijního programu v ošetřovatelství je náročný úkol, k němuž se zavázali studenti i fakulta.

Klíčová slova: kulturní kompetence; osnovy; transkulturní ošetřovatelství; vyšší vzdělání

\section{References}

1. Baumann A, Blythe J (2008). Globalization of Higher Education in Nursing. Online J Issues Nurs 13(2). DOI: 10.1111/ jonm.12121.

2. Bošković S, Ilić-Stošović D, Skočić-Mihić S (2017). Prilagodba na studij s obzirom na neka obilježja studenata s invaliditetom [Adjustment to college with regard to some characteristics of students with disabilities]. Revija za socijalnu politku [Croatian Journal of Social Policy] 24(1): 73-91. DOI: 10.3935/rsp. v24i1.1342.

3. Bradshaw C, Atkinson S, Doody O (2017). Employing a Qualitative Description Approach in Health Care Research. Glob Qual Nurs Res 4. DOI: 10.1177/2333393617742282.

4. Campesino M (2008). Beyond Transculturalism: Critiques of Cultural Education in Nursing. J Nurs Educ 47(7): 298-304. DOI: 10.3928/01484834-20080701-02.

5. Chang ES, Simon M, Dong X (2012). Integrating cultural humility into health care professional education and training. Adv Health Sci Educ Theory Pract 17(2): 269-278. DOI: 10.1007/s10459-010-9264-1.

6. Cruz JP, Estacio JC, Bagtang CE, Colet PC (2016). Predictors of cultural competence among nursing students in the Philippines:
A cross-sectional study. Nurse Educ Today 46: 121-126. DOI: 10.1016/j.nedt.2016.09.001.

7. Cupelli L (2016). An innovative service-learning project to develop cultural competency in undergraduate nursing students. Teach Learn Nurs 11(3): 113-117. DOI: 10.1016/j. teln.2016.01.004.

8. Elo S, Kyngas H (2008). The qualitative content analysis process. J Adv Nurs 62(1): 107-115. DOI: 10.1111/j.13652648.2007.04569.x.

9. Erlingsson C, Brysiewicz P (2017). A hands-on guide to doing content analysis. Afr J Emerg Med 7(3): 93-99. DOI: 10.1016/j. afjem.2017.08.001.

10. Gallagher RW, Polanin JR (2015). A meta-analysis of educational interventions designed to enhance cultural competence in professional nurses and nursing students. Nurse Educ Today 35(2): 333-340. DOI: 10.1016/j.nedt.2014.10.021.

11. Graneheim UH, Lundman B (2004). Qualitative content analysis in nursing research: concepts, procedures and measures to achieve trustworthiness. Nurse Educ Today 24(2): 105-112. DOI: 10.1016/j.nedt.2003.10.001.

12. Holloway I, Galvin K (2016). Qualitative Research in Nursing and Healthcare (4th ed.). Chichester: Wiley Blackwell, p. 87.

13. Holmgren J, Kraft M (2018). A global nursing framework in the Swedish Red Cross undergraduate nursing program. Nord J Nurs Res 38(3): 167-174. DOI: 10.1177/2057158517741268. 
14. Hyett N, Lee KM, Knevel R, Fortune T, Yau MK, Borkovic S (2018). Trialing Virtual Intercultural Learning With Australian and Hong Kong Allied Health Students to Improve Cultural Competency. J Stud Int Educ 23(3): 389-406. DOI: $10.1177 / 1028315318786442$.

15. Jeffreys MR (2014a). Academic Settings: General Overview, Inquiry, Action, and Innovation. In: Jeffreys MR (Ed.). Teaching Cultural Competence in Nursing and Health Care. 2nd ed. New York: Springer, pp. 117-182.

16. Jeffreys MR (2014b). Dynamics of Diversity: Becoming Better Health Care Providers through Cultural Competence. In: Jeffreys MR (Ed.). Teaching Cultural Competence in Nursing and Health Care. 2nd ed. New York: Springer, pp. 27-43.

17. Jeffreys MR (2014c). Overview of Key Issues and Concerns. In: Jeffreys MR (Ed.). Teaching Cultural Competence in Nursing and Health Care. 2nd ed. New York: Springer, pp. 3-26.

18. Kim H, Sefcik JS, Bradway C (2017). Characteristics of Qualitative Descriptive Studies: A Systematic Review. Res Nurs Health 40(1): 23-42. DOI: 10.1002/nur.21768.

19. Leininger M (2002). The Theory of Culture Care and the Ethnonursing Research Method. In: Leininger M, McFarland M (Eds). Transcultural Nursing: Concepts, Theories, Research and Practice. 3rd ed. New York: McGraw-Hill, pp. 71-98.

20. Ličen S, Plazar N (2015). Identification of nursing competency assessment tools as possibility of their use in nursing education in Slovenia - A systematic literature review. Nurse Educ Today 35(4): 602-608. DOI: 10.1016/j.nedt.2014.12.023.

21. Montenery SM, Jones AD, Perry N, Ross D, Zoucha R (2013). Cultural Competence in Nursing Faculty: A Journey, Not a Destination. J Prof Nurs 29(6): e51-e57. DOI: 10.1016/j. profnurs.2013.09.003

22. Pahor M, Domajnko B, Lindahl E (2015). Nursing students' perceptions of knowledge: an international perspective. Obzor Zdr Nege 49(1): 18-25. DOI: 10.14528/snr.2015.49.1.47.

23. Pajnkihar M, Vrbnjak D, Kasimovskaya N, Watson R, Stiglic G (2019). Perceptions of Caring Between Slovene and Russian Members of Nursing Teams. J Transcult Nurs 30(2): 195-204. DOI: 10.1177/1043659618788136.

24. Polit DF, Beck Tatano C (2014). Essentials of Nursing Research: Appraising Evidence for Nursing Practice. 8th ed. Philadelphia: Wolters Kluwer Health, p. 98.
25. Prosen M (2015). Introducing Transcultural Nursing Education: Implementation of Transcultural Nursing in the Postgraduate Nursing Curriculum. Procedia - Social and Behavioral Sciences 174: 149-155. DOI: 10.1016/j.sbspro.2015.01.640.

26. Prosen M (2018). Developing cross-cultural competences: for ensuring health and healthcare equality and equity. Obzornik zdravstvene nege 52(2): 76-80. DOI: 10.14528/ snr.2018.52.2.262.

27. Prosen M, Karnjuš I, Ličen S (2017). Razvijanje medkulturnih kompetenc med študenti zdravstvene nege. In: Rutar S, Čotar Konrad S, Štemberger T, Bratož S. (Eds). Vidiki internacionalizacije in kakovosti $v$ visokem šolstvu. Koper: University of Primorska Press, pp. 139-153.

28. Repo H, Vahlberg T, Salminen L, Papadopoulos I, LeinoKilpi H (2017). The Cultural Competence of Graduating Nursing Students. J Transcult Nurs 28(1): 98-107. DOI: $10.1177 / 1043659616632046$

29. Rinćić I, Muzur A, Bošković S (2014). The role of Faculty of Medicine in Rijeka in developing and promoting deaf culture: a few old experiences and a promising recent initiative with deaf education. JAHR: Europski časopis za bioetiku 5(2): 309-322.

30. Sagar PL (2014). Nursing Education and Transcultural Nursing. In: Sagar PL (Ed.). Transcultural Nursing Education Strategies. New York: Springer, pp. 1-21.

31. Sairanen R, Richardson E, Kelly H, Bergknut E, Koskinen L, Lundberg P, et al. (2013). Putting culture in the curriculum: A European project. Nurse Educ Pract 13(2): 118-124. DOI: $10.1016 /$ j.nepr.2012.08.002.

32. Sandelowski M (2000). Whatever happened to qualitative description? Res Nurs Health 23(4): 334-340 DOI: 10.1002/1098-240X(200008)23:4<334::AIDNUR9>3.0.CO;2-G.

33. Smit EM, Tremethick MJ (2013). Development of an international interdisciplinary course: A strategy to promote cultural competence and collaboration. Nurse Educ Pract 13(2): 132-136. DOI: 10.1016/j.nepr.2012.08.006.

34. Smythe E (2012). Discerning which qualitative approach fits best. New Zealand College of Midwives Journal 46: 5-12.

35. Wang Y, Xiao LD, Yan P, Wang Y, Yasheng A (2018). Nursing students' cultural competence in caring for older people in a multicultural and developing region. Nurse Educ Today 70: 47-53. DOI: 10.1016/j.nedt.2018.08.012. 